\title{
Batman ilindeki ince film a-Si teknolojili fotovoltaik sistemin performans değerlendirmesi
}

\author{
Osman PAKMA* \\ Batman Üniversitesi, Fen-Edebiyat Fakültesi, Fizik Bölümü,Batman \\ Geliș Tarihi (Recived Date): 04.10.2017 \\ Kabul Tarihi (Accepted Date): 07.12.2017
}

\section{Özet}

Bu çalışmada Batman ilinde ince film a-Si teknolojisine sahip $2.16 \mathrm{kWp}$ güce sahip şebeke bağlantılı sistemin bir yıllık elektrik enerjisi üretim verileri alınmış ve modüllerin performansı dış parametrelerde göz önüne alınarak değerlendirilmiştir. Sistem ölçümleri Ocak ayından Aralık ayına kadar tüm 2016 yılını kapsamaktadır. Ince film a-Si PV sistemden 2016 yılı süresince şebekeye 2.631 MWh enerji sağlanmıştır. Sistemin nihai verimi $\left(Y_{f}\right) 1.13$ den $4.89 \mathrm{kWh} / \mathrm{KWp} / g u ̈ n ' e$, performans oranı da (PO) $\% 53$ ile \%78 arasında de ğişmektedir. Ortam ve buna bă̆lı olarak modül sicaklıklarının sistem performansına etkisinin \%6 - \%9 arasında olduğu hesaplanmıştır. Ayrıca diğer sistem bölümlerinin de sistem performansı üzerinde değişen oranlarda etkili olduğu belirlenmiştir.

Anahtar Kelimeler: Fotovoltaik sistem, ince film, güneş hücresi, enerji, performans orant.

\section{Performance evaluation of thin film a-Si photovoltaic system for Batman province}

\begin{abstract}
In this study one year data of grid connected system with thin film a-Si technologies in Batman province which has $2.16 \mathrm{kWp}$ power and their module performance comparisons were evaluated according to external parameters. The data set covers from January until December 2016. The thin film a-Si PV system supplied 2.631 MWh energy to the grid during 2016. The final yield (Yf) this PV system ranged from 1.13 to $4.89 \mathrm{kWh} / \mathrm{kWp} /$ day and the performance ratio $(P O)$ ranged from 53 to $78 \%$. The effect of ambient and module temperatures on the system performance is calculated in the
\end{abstract}

\footnotetext{
*Osman PAKMA, osman@pakma.com, http://orcid.org/0000-0002-3098-0973
} 
range $6 \%$ to $9 \%$. It has also been determined that other parts of PV system affect system performance at various ratios.

Keywords: Photovoltaic system, thin film, solar cell, energy, performance ratio.

\section{Giriş}

Dünya üzerinde her yıl artan nüfus ile birlikte teknolojinin ilerlemesi enerji ihtiyacını arttırmaktadır. Enerji ihtiyacının çoğunluğu fosile dayalıdır. Fosil kaynaklarının en büyük sorunları tükenebilir olması ve küresel ssınmadır. Bu soruna engel kaynak ise hem temiz ve hem de yenilenebilir olmasıdır. Bu tür enerji kaynakları temiz ve yenilenebilir enerji kaynakları olarak isimlendirilmektedir. Temiz ve yenilenebilir enerji kaynaklarından en çok bilinenleri jeotermal enerji, hidroelektrik enerji, biokütle enerjisi, rüzgâr enerjisi ve güneş enerjisidir. Bu kaynaklardan en göze çarpanı ise güneş enerjisidir. Güneş enerjisinin diğer enerji kaynaklarından en büyük avantajı bol, temiz ve tükenmez bir kaynak olmasından dolayı yerel uygulamalar için kullanımını elverişli kılmakta ve her yerde faydalanılmasının önünü açmaktadır.

Her yıl dünya yüzeyine ulaşan güneş 1şınlarının enerjisi 80 milyar ton petrole eşdeğerdir (TOE). Bu değer dünyada her yıl tüketilen enerjinin yaklaşık 10000 katına eşittir ve fosile dayalı kaynakların tüm rezervlerinden elde edilen enerjiden daha fazladır [1]. Güneş enerji sistemleri gelişen teknoloji ile birlikte maliyetlerinde ki düşüş ile birlikte çevresel olarak temiz bir enerji kaynağı olarak kendini uluslararası alanda kabul görmüştür. Saat, hesap makineleri, yerleşim alanlarından uzak yerlerde kurulan telekomünikasyon uygulamaları ve uzaya gönderilen uydulara entegre edilen fotovoltaik (PV) uygulamalar ilk güneş enerjisi uygulamaları olarak hayatımıza girmişlerdir.

Birçok ülke güneş enerjisi üzerine yatırımlarını geliştirmiş ve enerji ihtiyaçlarının bir kısmını yenilenebilir enerji üzerine düzenlemiş iken ülkemizde fotovoltaik teknoloji ileri seviyelere ulaşmanın başlangıcı seviyesindedir. İlerleyen yıllarda Avrupa'da ve ülkemizde fotovoltaik enerjinin çalışmaları ile birlikte 2030 yılı için belirlenmiş kurulu güç hedefi 200 Gigawatt olarak hedeflenmiş ve tahminler doğrultusunda Dünya üzerinde 100 Gigawatt sınırının geçileceği beklentisi ile çalışmalar sürdürülmektedir.

Günümüze kadar yaygın olarak kullanılan güneş hücreleri kristal silisyum tabanlı hücreler olmuştur. Dünyadaki kurulu fotovoltaik sistemlerde yaklaşık olarak kullanımı $\% 90$ üzerindedir. Fakat kristal silisyum tabanlı güneş hücrelerinde malzeme üretim maliyetinin yüksek ve malzeme tüketiminin fazla olması nedeniyle bu alanda değişik seçenek olarak çok kristalli malzemelerin geniş ölçekte kullanılmasına neden olmuştur. Güneş pillerinde kullanılan malzemenin kalınlığının, maliyetlerinin düşürülmesi yönünde yapılan araştırma ve geliştirme çalışmaları, ince film teknolojisinin doğmasına neden olmuştur. Bu alanda yapılan araştırma ve geliştirme çalışmaları güneş pilleri üretiminde kullanılabilecek bir çok yarı-iletken malzemenin düşük maliyetlerde cam gibi tutucu tabakalar üzerinde geniş yüzeylere kaplanabileceğini göstermiştir. Başka bir deyişle ince film yarı-iletken malzeme, büyüklükleri bir milimetrenin binde birinden milyonda birine değin değișen damarlardan oluşmaktadır. Damarların genişliği kristalin kalitesi ile doğru orantılıdır [2]. İnce film güneş hücreleri arasında üç büyük aday öne çıkmaktadır. Bunlar; amorf-silisyum (a-Si), kadmiyum-tellür (CdTe) ve bakır-indiyum- 
galyum-selenyum $\left(\mathrm{Cu}(\mathrm{In}, \mathrm{Ga}) \mathrm{Se}_{2}\right)$ bileşik yarı-iletkenleridir. $\mathrm{Bu}$ sayılan malzemeler dışında son zamanlarda organik güneş hücreleri de yerini almıştır.

Bu çalışmada Batman'ın iklim koşullarına bağlı olarak toplamda 2,160 kWh kurulu gücünde ince film a-Si teknolojisine sahip PV sistemin performans analizi gerçekleştirilmiştir.

\section{Fotovoltaik sistemlerde performans oranı}

PV sistemlerde üretilen enerjinin verimliliği bir çok etkene bağlıdır. Sistem bileşenlerinin nominal karakteristik değerleri, sistem konfigürasyonu, sistemin bulunduğu coğrafi alan koşulları, sistem çevresinde bulunun gölgelenmeye neden olabilecek yapılar ve sistemin çalışma esnasında oluşabilecek elektronik arızalar gibi sorunlar sistemin enerji üretiminde kayılara sebep olup, sistemin verimliliğine etki etmektedirler. PV sistemlerin Performans Oranı (PO) [3-4].

$$
\begin{aligned}
P O & =\frac{\ddot{U} \text { retilen Enerji }(\text { Şebeke Çıkışı })}{\text { Referans Enerji }} \\
P O & =\frac{\ddot{U} \text { retilen Enerji }(\text { Şebeke Çıkışı })}{I \text { şınım } \times \text { Sistem Alanı } \times \text { STK'daki Modül Verimi }}
\end{aligned}
$$

Şebeke bağlantılı bir PV sistemin Performans Oranı (PO), sistemin AC çıkışında elde edilen enerjinin Standart Test Koşulları (STK (1000 W/m², $25{ }^{\circ} \mathrm{C}$, AM 1,5)) altında sistemdeki modüller tarafından üretilen enerjiye oranıdır. Şebeke çıkışında elde edilen PV sistem enerjisi, standart test koşulları altında modüller tarafından elde edilebilecek enerjiden sistem kayıpları çıkarılarak bulunabilir. PV sistemin kayıpları ne kadar az ise sistem o kadar yüksek bir Performans oranına (PO) sahip olacaktır.

PV güç sistemlerinde modülden elde edilen güç çıkışı ile anlık modül sıcaklığı arasında ters orantı vardır. Modül sıcaklığı arttıkça modülden alınan güç azalır. Sıcaklık arttıkça modülden elde edilen gücün azalmasında yaşanan kayıplar, modülü oluşturan hücrelerin sıcaklığı ile doğru orantılıdır. Ortam sıcaklığı yükseldikçe hücre sıcaklığı da yükselir ve üretilen enerjide kayıplara neden olur.

Güneş hücrelerinin, $800 \mathrm{~W} / \mathrm{m}^{2}$ 1şınım, $1 \mathrm{~m} / \mathrm{s}$ rüzgar ve $20{ }^{\circ} \mathrm{C}$ ortam sıcaklığ koşullarındaki sıcaklığına Hücre nominal çalışma sıcaklığı (Nominal Operating Call Temperature- $\mathrm{N}_{\mathrm{OCT}}$ ) adı verilir. Ürün kataloglarında ürün ile ilgili özellikler belirtilirken bu sıcaklık değeri altındaki özellikleri verilir. STK' da hücrenin sıcaklığını bulmak için ;

$\frac{\mathrm{T}_{\alpha}}{U_{L}}=\frac{\mathrm{T}_{c}, N o c t-\mathrm{T}_{a}}{G_{\tau}, N o c t}$

Burada $\mathrm{T}_{\alpha}$, modül soğurma katsayısı; $\mathrm{T}_{\mathrm{a}}, \mathrm{N}_{\mathrm{OCT}}$ koşulları için ortam sıcaklığı; $\mathrm{U}_{\mathrm{L}}$, kayıp katsayısı; $\mathrm{G}_{\tau}, \mathrm{N}_{\mathrm{OCT}}$ koşulları için ışınım değeri; $\mathrm{T}_{\mathrm{C}}$, modül kataloğunda belirtilen $\mathrm{N}_{\mathrm{OCT}}$ değeridir. 
Soğurma katsayısı, modül tarafından emilen 1şınımın modülün üzerine düşen 1şınıma oranı olarak ifade edilir. Yukarıdaki formül kullanılarak sıcaklığı bilinen bir ortam için hücre sıcaklığı hesaplanabilir [5-6].

$$
\mathrm{T}_{c}=\mathrm{T}_{a}+\left(G_{t} * \frac{\mathrm{T}_{\alpha}}{U_{L}}\right) *\left(1-\frac{u}{T_{\alpha}}\right)
$$

Burada $\mathrm{G}_{\mathrm{t}} 1$ şınım değeri, $u$ modül verimidir.

Normalize edilmiş sistem enerji üretimi $Y_{f}$, fotovoltaik sistemden elde edilmiş enerjinin evirici tarafından AC enerjiye dönüştürülmesinden sonra ortaya çıkan enerji değerini, STC koşulları altında verilen PV örgülerin kurulu güç değerine normalize edilmesiyle hesaplanmaktadır.

$$
Y_{f}=\frac{E_{\text {şebeke }}}{W_{p, e}}
$$

Bu ifade yer alan $E_{\text {şebeke }}$ fotovoltaik örgü tarafından üretilen ve şebekeye aktarılan AC enerjiyi (eviricinin çıkış enerjisi),$W_{p, e}$ ise fotovoltaik örgülerin STK altındaki kurulu güç değerini göstermektedir. Normalize edilmiş sistem enerji üretiminin birimi saat veya $\mathrm{kWh} / \mathrm{kWp}$ 'dır.

Normalize edilmiş fotovoltaik sistem enerji üretiminin, normalize edilmiş fotovoltaik örgü yüzeyi üzerine düşen 1 şınım enerjisine oranı olarak tanımlanan sistem performans oranı, PR, farklı bölgelerde ve farklı zamanlar üzerinden fotovoltaik sistemlerin performanslarını kıyaslamak ve değerlendirmek amacıyla kullanılmaktadır.

$$
P R=\frac{Y_{f}}{Y_{R}}
$$

olarak tanımlanır. $\mathrm{Bu}$ ifade, gerçek sistem enerji üretimi ile standart test koşulları altında tanımlı PV örgülerin verimlilik değerleri ile çalışan ideal sistemin enerji üretimi arasındaki oran olarak yorumlanabilinir.

\section{Fotovoltaik sistem}

Sistem kurulumu Batman'da bulunan Özel Çözüm İlkokulu (enlem: 37.921; boylam: 41.144) çatısına yapılmıştır. Sistemde toplam 24 adet ince film amorf silisyum fotovoltaik modül kullanılmıştır. Çizelge 1 'de sistemde kullanılan fotovoltaik modüllerin STK altındaki teknik verileri verilmiştir.

Çizelge 1. Sistemde kullanılan fotovoltaik modüllerin STK altındaki teknik verileri.

\begin{tabular}{|l|l|}
\hline Üretici Firma & Sunset \\
\hline Kod & SunOne AS 90 \\
\hline Teknoloji & İnce film amorf silisyum \\
\hline Maksimum güç noktası $\mathrm{P}_{\max }(\mathrm{W})$ & 90 \\
\hline Maksimum güç noktasındaki gerilim $\mathrm{V}_{\mathrm{mpp}}(\mathrm{V})$ & 102 \\
\hline Maksimum güç noktasındaki akım $\mathrm{V}_{\mathrm{mpp}}(\mathrm{V})$ & 0.91 \\
\hline
\end{tabular}


Çizelge 1. (Devamı).

\begin{tabular}{|l|l|}
\hline Aç1k devre gerilim $\mathrm{V}_{\mathrm{oc}}(\mathrm{V})$ & 137 \\
\hline K1sa devre akımı $\mathrm{I}_{\mathrm{sc}}(\mathrm{A})$ & 1.15 \\
\hline Alan $\left(\mathrm{m}^{2}\right)$ & 1.43 \\
\hline NOCT $\left({ }^{\circ} \mathrm{C}\right)$ & 50 \\
\hline$\beta\left(\% /{ }^{\circ} \mathrm{C}\right)$ & -0.34 \\
\hline$\alpha\left(\% /{ }^{\circ} \mathrm{C}\right)$ & +0.04 \\
\hline$\gamma\left(\% /{ }^{\circ} \mathrm{C}\right)$ & -0.22 \\
\hline
\end{tabular}

Sistemde Sunset firmasına ait SunString 5000 evirici kullanılmıştır. Sistem için seçtiğimiz model eviricinin bünyesinde;

- $\mathrm{AC}$ ve DC tarafında aşırı gerilim yakalayıcı

- 1 fazlı şebeke kontrolü

- Sicaklık kontrolü

- Şebeke arızalarından korumak için EMW filtresi bulunmaktadır.

Modül sıcaklıklarını ölçmek için ise K tipi platinyum sensörler kullanılmıştır. Sistem aktif olduğu sürece şu değerler ölçülerek kaydedilmiştir:

- Sistem üzerinden şebekeye aktarılan güç $(W)$

- Sistemin aktif olduğu andan itibaren ürettiği toplam enerji miktarı (Wh)

- Modül sicaklığı $\left(C^{\circ}\right)$

- Aylık üretilen toplam güç $(k W h)$

- Anlık üretilen toplam güç $(k W h)$

24 adet SunsetSunOne AS 90 ince film amorf silisyum modüller, üçerli seri halinde $30^{\circ}$ eğimli, 8 adet dizi oluşturularak $2.160 \mathrm{kWp}$ gücünde örgü elde edilmiş ve çatı düzleminde kullanılan alan ise $30 \mathrm{~m}^{2}$, dir. Şekil 1'de sistem görülmektedir.

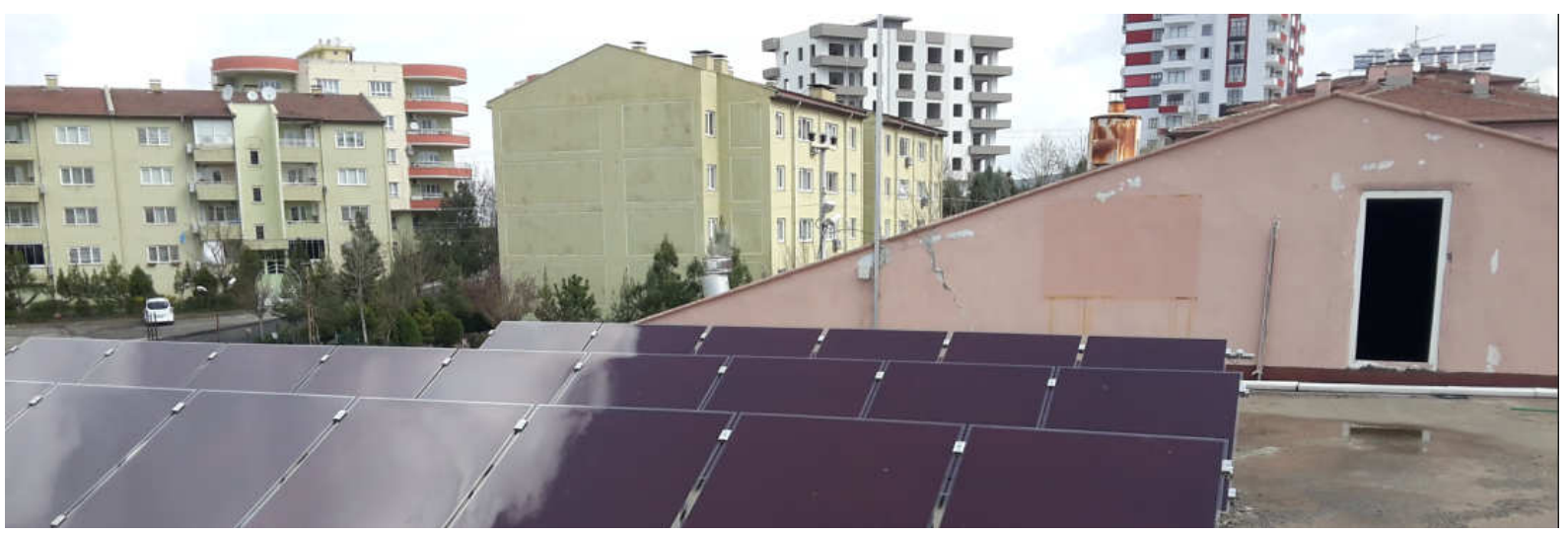

Şekil 1. Kurulu ince film a-Si PV Sistem.

Gelen anlık güneş 1şınımı şiddetini Dünya Meteoroloji Teşkilat (WMO) tarafından önerilen Kipp\&Zonen firmasının üretmiş olduğu CMP11 piranometresinden faydalanılmıştır. Anlık ortam sıcaklık değerleri HMP60 Vaisala INTERCAP sıcaklık ve nem sensörü yardımıyla ölçülmüştür. Piranometre ve sensörler, güneş hücresi destekli akü yardımıyla veri depolama aygıtı olan CR800 dataloggera bağlanmıştır. Belli günlerde dataloggerda kaydedilen veriler RS232 arayüzü ile bilgisayar ortamına aktarılmıştır. 
Sistem ölçümleri 01.01.2016-31.12.2016 tarihleri arasında 1 yıllık ölçümleri kapsamaktadır.

\section{Sonuçlar}

Batman ilinde Özel Çözüm İlkokulu (enlem: 37.921; boylam: 41.144) çatısına kurulmuş sistemde yer alan piranometre ve sıcaklık sensörü yardımıyla 2016 yılına ait aylık ortalama ölçüm değerleri Çizelge 2'de verilmiştir.

Çizelge 2. Yıllık güneş 1şınımı ve sıcaklık ölçüm sonuçları.

\begin{tabular}{|c|c|c|}
\hline $\begin{array}{c}\text { Aylar } \\
(2016)\end{array}$ & $\begin{array}{c}\text { Ĕ̆imli Yüzeye }\left(30^{\circ}\right) \text { Gelen Ortalama } \\
\text { Günlük Güneş Işınım Şiddeti }\left(\mathrm{kWh} / \mathrm{m}^{2} \text {.gün) }\right.\end{array}$ & $\begin{array}{c}\text { Aylık Ortalama Günlük } \\
\text { Sicaklık Değerleri }\left({ }^{\circ} \mathrm{C}\right)\end{array}$ \\
\hline OCAK & 2.35 & 1.85 \\
\hline ŞUBAT & 3.18 & 8.83 \\
\hline MART & 5.02 & 11.17 \\
\hline NİSAN & 5.98 & 16.7 \\
\hline MAYIS & 6.13 & 20.94 \\
\hline HAZİRAN & 7.23 & 27.23 \\
\hline TEMMUZ & 7.11 & 31.9 \\
\hline AĞUSTOS & 7.01 & 32.93 \\
\hline EYLÜL & 6.68 & 25.67 \\
\hline EKİM & 4.61 & 20.29 \\
\hline KASIM & 3.21 & 9.75 \\
\hline ARALIK & 1.87 & 3.81 \\
\hline
\end{tabular}

Batman ili Özel Çözüm İlkokulu çatısına kurulan $2.160 \mathrm{kWp}$ gücünde ince film amorf silisyum örgü sistemlerinde üretilen 2016 yılına ait veriler Şekil 2'de verilmiştir. Yıllık dönem içerisinde ince film amorf silisyum örgü sisteminden $2.631 \mathrm{MWh}$ enerji üretilmiştir.

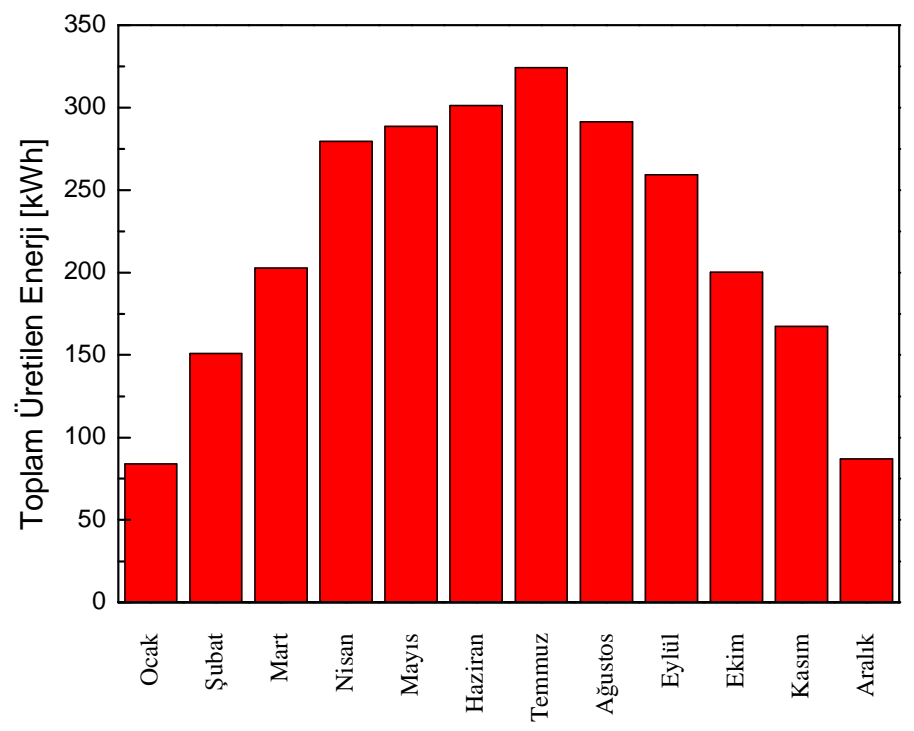

Şekil 2. PV örgünün aylık ürettiği enerji. 
Şekil 3'de aylık ortalama hava ve modül sıcaklığı değerleri verilmiştir. Görüldüğü gibi yaz aylarında ortalama hava sicaklığ $15-32{ }^{\circ} \mathrm{C}$ arasında, ortalama modül sicaklığ ise 28-38 ${ }^{\circ} \mathrm{C}$ arasında değişmektedir. Kış aylarında ise, ortalama hava sıcaklığı $2-15{ }^{\circ} \mathrm{C}$ arasında, ortalama modül sıcaklığı ise $22-28{ }^{\circ} \mathrm{C}$ arasında değişmektedir.

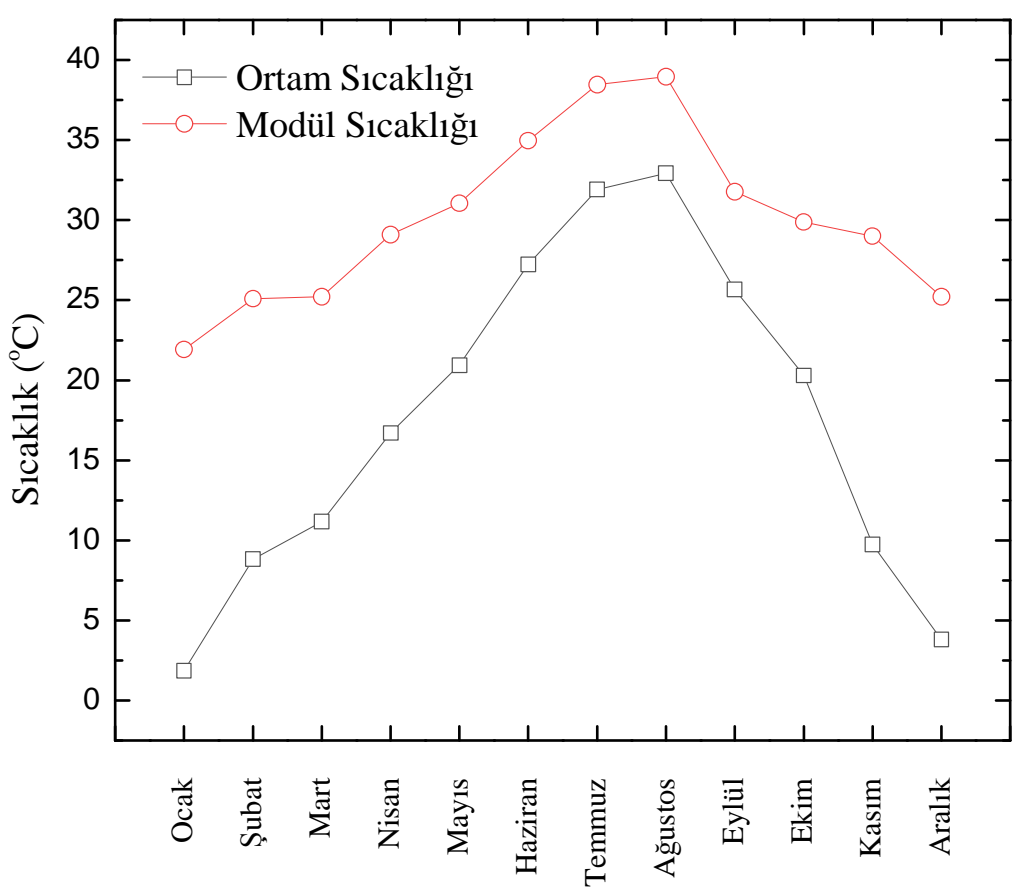

Şekil 3. 2016 yılı için aydınlanma süresince ölçülen aylık ortalama saatlik ortam ve modül sıcaklığı değerleri

Sıcaklık kayıp katsayısı şu şekilde bulunabilir:

$\eta_{s c c}=1+\beta\left(T_{C}-25\right)$

Burada $\beta$ Çizelge 1'de görüldüğü gibi modül sıcaklık katsayısıdır.

Ölçülmüş olan güneş 1şınım şiddeti değerleri ve şebekeye bağlı $2.160 \mathrm{kWp}$ gücünde ince film amorf silisyum örgü sisteminin üretmiş olduğu günlük ortalama enerji değerleri kullanılarak sistemin performans değerlendirilmesi yapılmıştır. Ölçülmüş̧ 1şınım şiddeti değerlerinden faydalanarak normalize edilmiş örgü yüzeyine düşen 1şınım enerjisi $\left(Y_{R}\right)$ aylara göre hesaplanmıştır. Ayrıca SunOne AS 90 kodlu ince film amorf silisyum modülünün STK değerlerinden ve sistemin elde ettiği enerji değerlerinden de faydalanarak normalize edilmiş sistem enerji üretimi $\left(\mathrm{Y}_{\mathrm{f}}\right)$ aylara göre hesaplanmıştır. $\mathrm{Bu}$ değerlerden faydalanarak da sistem performans oranı tayin edilmiştir. Şekil 4'de normalize edilmiş örgü yüzeyine düşen ışınım enerjisi ve ince film amorf silisyum örgü sisteminden elde edilmiş normalize edilmiş sistem enerji üretimi değerleri aylara göre çizilmiştir. Şekil 5'de ise ince film amorf silisyum örgü sisteminin performans oranı aylara göre gösterilmiştir. 
PAKMA $O$.

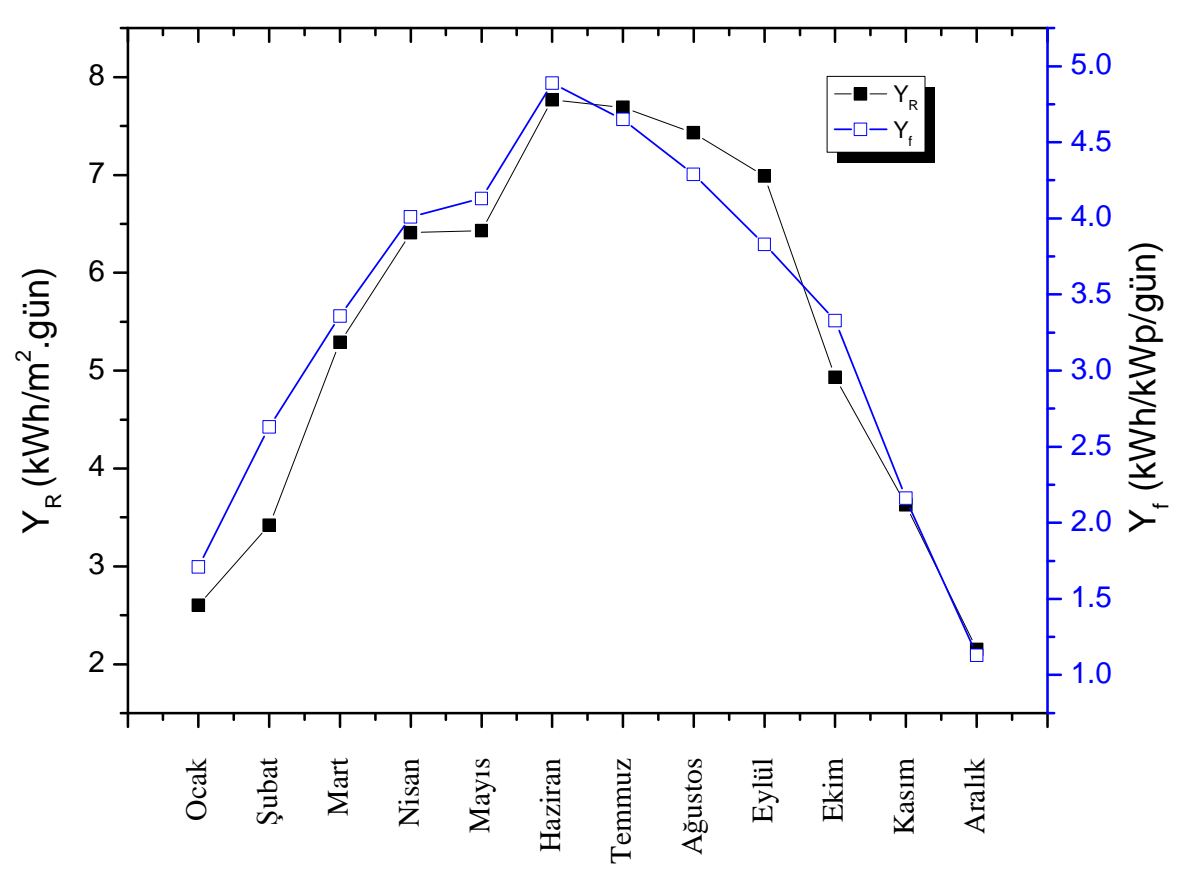

Şekil 4. Aylık $Y_{R} \operatorname{veY}_{f}$ değerleri.

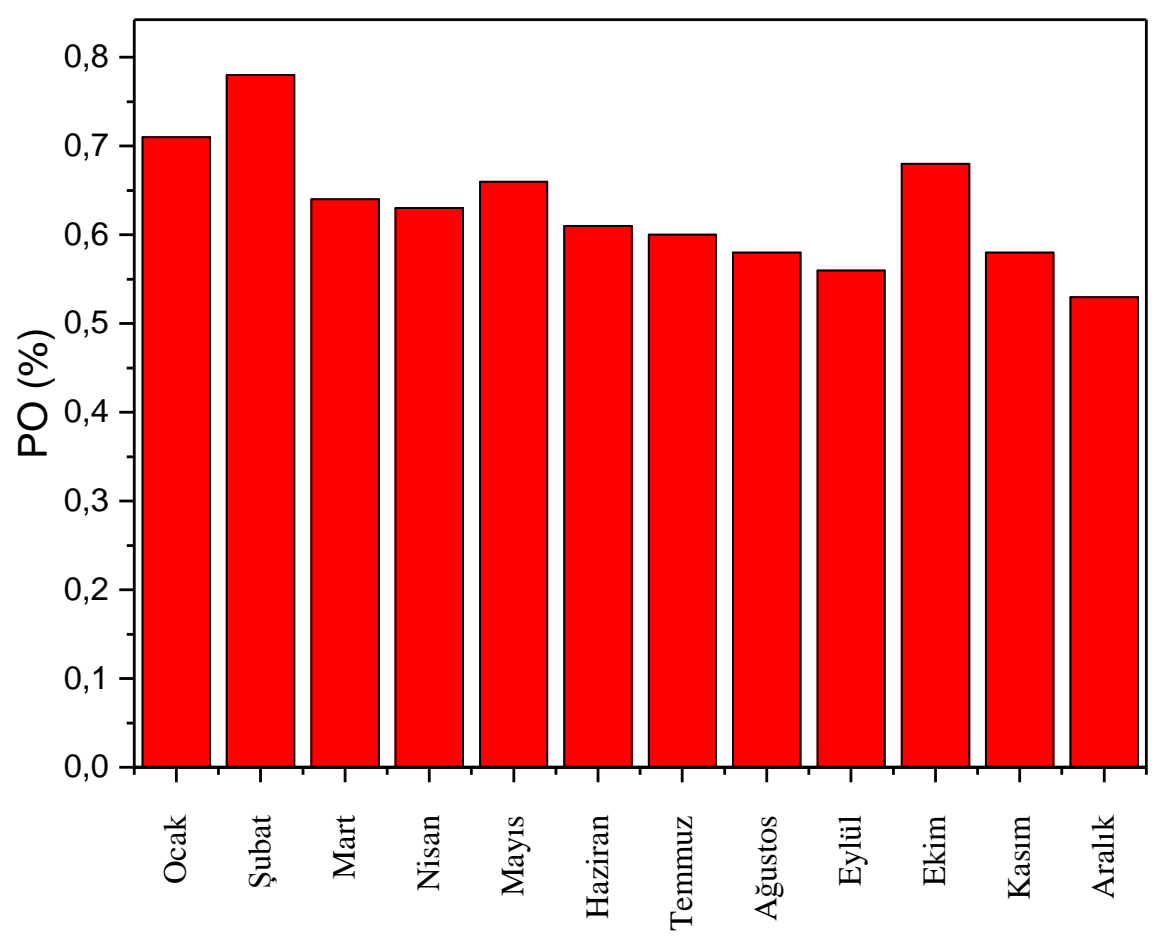

Şekil 5. Normalize edilmiş PV modül güç değerlerinin aylık performans oranları.

Yapılan ölçümlerde en yüksek 1şınım değerlerinin Haziran 2016 ile Ağustos 2016 ayları arasını, en düşük ışınım değerlerinin de Kasım 2016 ile Şubat 2016 tarihleri arasını kapsadığı görülmüştür. Ölçülen sıcaklık değerlerinin de buna paralel olduğu görülmektedir. Yıllık elde edilen çıkış gücü ince film amorf silisyum sistemi için 2.631 
MWh olarak ölçülmüştür. Ölçülen veriler doğrultusunda hesaplamalar yapılmış, örgü sistemlerinin enerji üretimi ve kayıplar STK koşulları altındaki değerlere normalize edilmiştir. $\mathrm{Bu}$ değerler; normalize edilmiş örgü yüzeyine düşen 1 şınım enerjisi $\left(Y_{R}\right)$, normalize edilmiş örgü sisteminin enerji üretimi $\left(\mathrm{Y}_{\mathrm{f}}\right)$ ve sistem performans oranı (PO) olarak sıralanmıştır. Haziran- Mayıs tarihleri arasındaki ince film amorf silisyum PV sisteminin performans oranının diğer aylara göre karşılaştırıldığında; ortam sıcaklığı arttığı için azalmıştır. Şekil 4'den de görüleceği üzere sistemin performans oranı kayıpları \% 20-40'lara tekabül etmektedir. Eşitlik (3), (4) ve (7) yardımıyla modül sıcaklığının performansa etkisi aylara göre \% 6-9 arasında değişmektedir. Diğer kayıların ise; eviriciden kaynaklanan kayıplar, kablolamadan kaynaklanan kayıplar ve belli günlerde modüllerdeki tozlanmadan kaynaklanan kayıpların büyük ölçüde etki ettiği düşünülmektedir. Sonuç olarak, çalışma koşulları gereği dış ortamda kullanılan fotovoltaik modüller, özellikle yaz aylarında yüksek sıcaklıklara maruz kalabilmektedir. Hava sicaklığının $40{ }^{\circ} C^{\prime}$ yi bulduğu durumlarda panelin sicaklığı, cam yüzey ve metal çerçeve nedeniyle yüksek sıcaklıklara çıkmaktadır. Artan sıcaklık, modülü oluşturan güneş hücreleri içerisindeki yük taşıyıcı sayısını arttırarak toplam akımı arttırıcı katkıda bulunurken diğer yandan yasak enerji bant aralığını düşürerek voltajı azaltmaktadır. Toplam akım artışı voltajdaki azalmayı kompanze edemediğinden $25^{\circ} \mathrm{C}$ ve üzerinde PV modül çıkış gücü ve verim azalmaktadır. Bu nedenle, fotovoltaik modüllerin artan sıcaklıklardan olumsuz yönde etkilenmemesi için yeterli havalandırmanın sağlanması, ısınmayı önleyici yüzeylerle kaplama, ısı üretecek kaynaklardan uzağa montaj gibi tedbirler alınır.

\section{Kaynaklar}

[1] Nebbia G.,Twentytwenty-five, Futures, 33, 43-54 (2001).

[2] Pakma O.,ZnO/CdS/CuIn(S,Se $)_{2}$ heteroeklem güneș pillerinde admittans spektroskopisi ve akımiletim mekanizmaları, Yüksek Lisans Tezi, Muğla Üniversitesi (2002).

[3] Canete C.,Carretero J.andSidrach-de-Cardona M., Energy performance of different photovoltaic module technologies under outdoor conditions, Energy, 65, 295-302 (2014).

[4] Ferrada P., Araya F., Marzo A.and Fuentealba E., Performance analysis of photovoltaic system of two different technologies in a coastal desert climate zone of Chile, Solar Energy, 114, 356-363 (2015).

[5] Segado P.M., Carretero J., Sidrach de Cardona M., Models to predict the operating temperature of different photovoltaic modules in outdoor conditions, Progress in Photovoltaics, 23 (10), 1267-1282 (2015).

[6] Skplaki E. andPalyvos J.A., On the temperature dependence of photovoltaic module electrical performance: A review of efficiency/power correlations, Solar Energy, 83, 614-624 (2009). 